DOI: http://doi.org/10.15688/nav.jvolsu.2017.1.1

UDC 94(470.4).01

LBC 63.3(235.4)2-9

\title{
ABOUT THE ELITE OF MIDDLE SARMATIAN SOCIETY BASED ON ARCHAEOLOGICAL MATERIALS OF THE LOWER VOLGA REGION ${ }^{1}$
}

\author{
Anatoliy S. Skripkin \\ Volgograd State University, Volgograd, Russian Federation
}

\begin{abstract}
The problem of allocation of the elite from the middle Sarmatian society is studied on the basis of written and archaeological sources. The data of written sources allow us to characterize ethno-tribal Sarmatian unions as complex societies that assume the presence of different levels of nobility and the main mass of the free population. The highest categories of Sarmatian elite are represented by such titles as kings and "skeptukhs". Archaeological materials of Middle Sarmatian culture of the Lower Volga region enable us to select a group of elite burials, the hallmarks of which are the size of the mound, a broad rectangular burial pits and the construction of hiding places. Items of material culture are represented there by symbols of power: the pectoral, the torque and golden bracelets; silver and bronze cookware sets and clothes decorated with gold plaques. Some of them can be interpreted as the king's things, but others, apparently, belonged to "skeptukhs". There is a group of wealthy female burials which might belong to the priestesses.

Because of sources' condition it is difficult to distinguish between the burials of the kings and "skeptukhs". Presumably, the king burials might be in a mound near the village of Oktyabrsky, in the mounds near the village of Kosika and at the station of Berdia. The burials of the professional priestesses belonged to Middle Sarmatian society and had the special status. They were found in the burial mounds 45 and 51 near the Peregruznoe village.

Key words: the Sarmatians, Middle Sarmatian culture, the elite of the Middle Sarmatian society, written and archaeological sources, symbols of power, kings, skeptukhs, priestesses.
\end{abstract}

Citation. Skripkin A.S., 2017. About the Elite of Middle Sarmatian Society Based on Archaeological Materials of the Lower Volga Region. The Lower Volga Archaeological Bulletin, vol. 16, no. 1, pp. 5-18. (in Russian).

УДК 94(470.4).01

ББК 63.3(235.4)2-9

\section{ОБ ЭЛИТЕ СРЕДНЕСАРМАТСКОГО ОБЩЕСТВА ПО ДАННЫМ ПИСЬМЕННЫХ ИСТОЧНИКОВ И АРХЕОЛОГИЧЕСКИМ МАТЕРИАЛАМ НИЖНЕГО ПОВОЛЖЬЯ ${ }^{1}$}

\section{Анатолий Степанович Скрипкин}

Волгоградский государственный университет, г. Волгоград, Российская Федерация

Аннотация. Проблема выделения элиты среднесарматского общества рассматривается на основе пись-менных и археологических источников. Данные письменных источников позволяют характеризовать этнопле-менные сарматские объединения как сложные общества, которые предполагают наличие разных уровней знати и основной массы свободного населения. Высшие категории сарматской элиты представлены такими титулами, как цари и скептухи. Археологические натериалы среднесарматской культуры Нижнего Поволжкбя 
позволяют выделить группу элитных погребений, отличительными признаками которых являются размеры курганной насыпи, наличие широких прямоугольных могильных ям, сооружение тайников. Предметы материальной культуры в них представлены символами власти - пекторалью, гривной, а также браслетами из золота; серебряными и бронзовыми наборами посуды; одеждой, украшенной золотыми бляшками. Некоторые из них могут интерпретироваться как царские, другие, видимо, принадлежали скептухам. Выделяется группа богатых женских захоронений, принадлежащих, по всей вероятности, жрицам.

По состоянию источников трудно провести разграничение между погребениями царей и скептухов. Предположительно, царскими могут быть захоронения в кургане у пос. Октябрьский, в курганах у с. Косика и ст. Бердия. К числу статусных в среднесарматской культуре относились и захоронения профессиональных жриц, к которым могут быть отнесены захоронения в курганах 45 и 51 у с. Перегрузное.

Ключевые слова: сарматы, среднесарматская культура, элита среднесарматского общества, письменные и археологические источники, атрибуты власти, цари, скептухи, жрицы.

Цитирование. Скрипкин А. С., 2017. Об элите среднесарматского общества по данным письменных источников и археологическим материалам Нижнего Поволжья // Нижневолжский археологический вестник. Т. 16, № 1. С. 5-18.

\section{Данные письменных источников.}

В письменных источниках содержится крайне мало информации по этой проблеме. Чаще упоминаются представители высшего социального ранга. До нас дошли имена сарматских царей: Арифарн, Сайтофарн, Гатал, Абеак, Спадин, Эвнон, Фарзой, Инисмей, царица Амага и некоторые другие ${ }^{2}$. Деятельность отдельных из них относится к рассматриваемому времени или близкому к нему. Так, например, Страбон приводит интересные данные о решении боспорского правителя Фарнака, сына Митридата VI, отвоевать у римлян владения своего отца в Малой Азии, для чего он привлекает воинские контингенты сарматов: сираков, аорсов и верхних аорсов. Эти кочевнические группировки возглавляли цари: сираков - Абеак, аорсов - Спадин, имя царя верхних аорсов Страбон не называет, но оно явно подразумевается (Strabo, XI, V, 8). Аopсы и верхние аорсы, по данным того же Страбона, обитали в Волго-Донских степях и являлись одним из компонентов формирования среднесарматской культуры.

В событиях так называемой сирако-аорской войны (середина I в. н.э.), связанных с борьбой за боспорский престол, Тацит упоминает царя аорсов Эвнона, выступившего со своей конницей на одной из противоборствующих сторон (Annal, X, 15-21).

К среднесарматскому времени (вторая половина I в. н.э.) относится деятельность сарматских царей Фарзоя и Инисмея, известных по нумизматическому материалу Ольвии, которые, по мнению исследователей, возглавля- ли аорское или аланское объединение [Симоненко, Лобай, 1991, с. 62-75; Скрипкин, 1996, c. 160-169].

Тацит приводит данные о том, что у сарматов были предводители, ранг которых определялся термином «скептух». Так, повествуя о походе сарматов в 35 г. н.э. в Закавказье, он отмечал, что во главе двух сарматских группировок стояли скептухи (Annal, VI, 31-33), хотя Тациту было известно, что у сарматов были цари, это следует из его описания сирако-аорской войны 49 г. н.э.

Можно предположить, что в иерархическом отношении скептухи стояли ниже царей. Это следует из сообщения Страбона. Описывая народы побережья Черного моря, в частности гениохов, он отмечает, что «Управляют ими так называемые скептухи, а эти последние сами подвластны тиранам и царям» (Strabo, XI, II, 13).

Для исследования социальной структуры сарматского общества имеют значение два важных фактора. Первый из них - определение уровня его политической организации, второй, поскольку из письменных источников следует, что все взрослое сарматское мужское население составляло воинский контингент, выявление воинской иерархии в структуре их военной организации.

Прямых указаний на политическую организацию сарматского общества в письменных источниках нет, некоторую информацию по этому вопросу можно получить из содержащихся в них косвенных данных. Интересующие нас сведения появляются начиная с бур- 
ных событий эпохи Митридата VI Евпатора, когда сарматы часто стали принимать участие в конфликтах между различными противоборствующими сторонами. Характерной чертой этих сообщений является то, что сарматы в них обычно не выступают как единое политическое целое. Так, например, в упомянутом выше эпизоде, относящемся ко времени правления на Боспоре Фарнака, называются три сарматских группировки: сираки, аорсы и верхние аорсы, в одно и то же время возглавляемые своими царями. Каждая из этих группировок занимала ограниченную территорию между Каспийским морем, Меотидой и Танаисом (Strabo, XI, V, 8). В данном случае эти самостоятельные сарматские группировки, видимо, должны были выступить консолидированно в качестве наемников в армии боспорского царя.

Были случаи, когда кочевники, обитавшие на территории Сарматии, выступали друг против друга, являясь союзниками противоборствующих сторон. Одним из известных таких примеров являются события сиракоаорской войны 49 г. н.э., изложенные Корнелием Тацитом (Annal, XII, 15-21). В это время на Боспоре разгорелся очередной конфликт за власть между братьями Митридатом VIII и Котисом. Митридат, потомок понтийских Митридатов, будучи правителем Боспорского царства, придерживался антиримской политики и был с помощью римлян низложен с престола. Его вынудили бежать на азиатскую часть Боспора, где он стал создавать коалицию, опираясь на которую рассчитывал вернуть власть над царством. Правителем же на Боспоре в это время стал Котис, поддерживаемый римлянами. На стороне Митридата выступили сираки во главе с царем Зорсином. Котис и римляне привлекли на свою сторону аорсов, которых возглавлял царь Эвнон. Перипетии этих событий с кровопролитными эпизодами закончились победой Котиса и его союзников, а Митридат в конечном счете был выдан римлянам. Этот эпизод ярко свидетельствует о самостоятельности сарматских подразделений, известных в письменных источниках под разными названиями.

Тот же Тацит сообщает еще об одном инциденте, произошедшем в 35 г. н.э. в Закавказье, в котором приняли участие сарматы, выступившие за разные воюющие стороны (Annal, VI, 31-33). Речь в данном случае идет о противостоянии Рима и Парфии, в которое были втянуты и другие государства: Армения, Иберия и Албания. В один из периодов обострения ситуации в этом районе иберы нападают на Армению, что вызвало негативную реакцию Парфии. Иберийский правитель Фарасман обращается за помощью к сарматам. Те, по словам Тацита, приняв подарки от обеих сторон, по обычаю своего племени отправились на помощь к той и другой стороне. Сарматы, которые решили прийти на помощь иберам, были пропущены ими через кавказские проходы. Сарматы же, шедшие на помощь парфянам и Армении, не смогли воспользоваться этими проходами, поскольку иберы закрыли их. Участие сарматов в решающем сражении на стороне иберов определило его исход, парфяне потерпели поражение. Этот эпизод в передаче Тацита можно воспринимать по разному: как участие отдельных подразделений одного сарматского объединения за разные конфликтующие стороны и как участие разных сарматских группировок в этих событиях, возможно тех же аорсов и сираков. У Тацита они фигурируют под общим названием «сарматы».

В 1984 г. в Крыму у Мангупа был обнаружен эпиграфический документ, представляющий собой фрагмент мраморной плиты с текстом декрета, предположительно ольвийского происхождения. В декрете речь идет о тяжелом экономическом и политическом положении, в которое попала предполагаемая Ольвия, и чествуемый ее гражданин на свои средства сумел добыть продовольствие, а также совершить посольства в римскую провинцию Мезию и к «величайшим царям Аорсии». Декрет датируется I в. н.э. [Виноградов, 1994, с. 165-169].

Что собой представляла Аорсия, каков ее политический статус? В источнике на этот счет какая-либо информация отсутствует. Трудно даже определить точное ее местонахождение [Щукин, 1995, с. 177]. Некоторые исследователи считали Аорсию раннегосударственным образованием [Симоненко, Лобай, 1991 , с. 85 ; Зубарь, 1998, с. 46]. Сомнения на счет существования единого сарматского царства Аорсии, предположительно располагав- 
шегося во второй половине I в. н.э. между Днепром и Дунаем, возникают в связи с организацией посольства чествуемым ольвеополитом сразу к нескольким ее царям. При условии, что Аорсия - это некое единое государственное образование, править в ней должен был в конкретный момент, о котором идет речь в декрете из Мангупа, один царь. Поскольку в декрете все же речь идет о посольстве сразу к нескольким «величайшим царям Аорсии», то в этом случае она не могла представлять собой единое целое в политическом отношении. При такой трактовке Аорсия должна, видимо, восприниматься как географическая область, в пределах которой располагалось несколько сарматских объединений, имевших своих правителей. Видимо, так воспринималась реальность того времени жителями Ольвии, поскольку другие источники, в частности сочинения римских авторов, такого государственного образования, граничащего с империей по Дунаю, не знают. Показательный пример этому - данные Плиния Старшего, относящиеся к рассматриваемому времени. На территории предполагаемой Аорсии, от Дуная вдоль побережья Черного моря, он помещает целый ряд сарматских народов, в том числе гамаксобиев или аорсов, аланов и роксоланов, которые, надо полагать, были самостоятельны в политическом отношении (Plin, NH, IV, 80).

В I в. н.э. в восточноевропейских степях появляются аланы, свое присутствие здесь они обозначили участием в военных акциях в основных конфликтных районах: в Закавказье и Подунавье. Было высказано мнение, что аланы впервые объединяют большую часть сарматских племен. Такое утверждение основывалось на сообщении Аммиана Марцеллина (330-395 гг.) об аланах, что «они малопомалу постоянными победами изнурили соседние народы и распространили на них название своей народности, подобно персам» (XXXI, 2, 13). Но, видимо, в среднесарматское время такого объединения еще не произошло, да и само высказывание Аммиана Марцеллина предполагает длительность процесса. По крайней мере, во второй половине I в. н.э. основные сарматские подразделения сохраняют свою независимость и упоминаются наряду с аланами. И, как было сказано выше, Плиний, последовательно располагая разные народы от Истры вдоль Черного моря, аланов помещает между аорсами и роксоланами. Примерно в то же время и на той же территории эпиграфический источник упоминает не Аланию, а Аорсию.

Попытка обосновать образование аланской кочевой империи в I-II вв. н.э. с центром на Нижнем Дону была предпринята С.А. Яценко [Яценко, 2008б, с. 281-310]. Его реконструкция вызвала резкую критику со стороны известных исследователей, указавших на необъективный анализ автором источников [Перевалов, 2014, с. 2-9; Раев, 2016, с. 122-126].

Эти примеры показывают, что сарматский мир, по крайней мере на рубеже эр и в начале новой эры, не был единым, он состоял из ряда самостоятельных этнополитических группировок, скорее всего уровня сложных вождеств. Для создания крупного политического объединения, включающего большую часть сарматских подразделений, как, например, «имперская конфедерация» [Барфилд, 2009 , с. 43.] с внешними элементами государственности, не было одного главного условия. В специальной литературе оно формулируется следующим образом: возникновение институтов государственности у кочевников предполагает достаточно большую численность и экономический потенциал подчиненного населения; степень централизации кочевников прямо пропорциональна величине соседней земледельческой цивилизации [Хазанов, 2002, c. 364; Крадин, 2007, с. 319]. Классическим примером такой ситуации является образование в конце III в. до н.э. хуннской кочевой державы как реакции на объединение Китая в единое централизованное государство под властью Циньской, а затем и Ханьской династий.

Что собой представлял оседлый мир, с которым в течение ряда веков соседствовали сарматы? Античные полисы Северного Причерноморья являлись небольшими государственными образованиями. Даже Боспорское царство по экономическим и политическим возможностям не могло идти ни в какое сравнение, например, с Ханьской империей, к тому же, по крайней мере со времени Августа, находившееся в зависимости от Рима [Зубарь, 1998, с. 36].

Соседство сарматов юго-востока Европы с большим количеством государственных 
образований со своими политическими интересами не способствовало объединению кочевников, относимых античными авторами к сарматам, созданию единого этнополитического объединения уровня «имперской конфедерации». Отличительными признаками этой высшей политической организации кочевого общества считаются, например, следующие: наличие института наместничества, деление конфедерации на две или три части - два крыла или два крыла и центр, обширные территории с населением, исчисляемым многими сотнями тысяч человек [Бондаренко, Коротаев, Крадин, 2002, с. 15]. Все эти признаки не являются характерными для сарматских объединений, упоминаемых в письменных источниках под собственными названиями. Как уже отмечалось выше, их объединения не превышали уровень сложных вождеств, в состав которых входили простые вождества. Такая ситуация предполагает наличие двух уровней сарматской знати. Первый - это общий предводитель всего объединения (царь) и второй - главы отдельных вождеств, входящих в это объединение, предположительно скептухи.

Второй фактор, требующий выяснения, касается организации войска сарматов и внутривойсковой иерархии. В письменных источниках имеются противоречивые сведения о том, что кроме традиционной конницы сарматское войско включало еще и пехоту. Так, в описании событий, связанных с борьбой за власть в конце IV в. до н.э. на Боспоре, упоминается Арифарн, который, по мнению большинства исследователей, возглавлял военную группировку сарматского круга, состоящую из 20-тысячной конницы и 22-тысячной пехоты (Diod, XX, 22). Лукиан Самосатский в сочинении «Токсарид или дружба», составленном в форме диалога, повествуя о нападении савроматов на Скифию, отмечал, что армия савроматов состояла из 10 тыс. всадников и втрое больше пехоты [Скифы, 1992, с. 219]. В данном сюжете речь, скорее всего, идет о сарматах. Во времена Лукиана (II в. н.э.) оба созвучных этнонима употреблялись как равнозначные. В то же время Тацит утверждал, что никто так не бессилен в пешем сражении, как сарматы, доблесть их проявлялась в конном бою (Hist, I,79, 1-4).

Исследователи не исключали наличие пехоты у сарматов [Хазанов, 2008, с. 151, 152].
В таком случае статус пешего воина должен быть ниже, нежели конного. Все же, как полагал А.М. Хазанов, пехота не играла существенной роли в военном деле сарматов.

А.М. Хазанов ранее считал, что начиная с I в. до н.э. и в первые века н.э. сарматская конница подразделялась на тяжеловооруженную (катафрактарии) и легковооруженную. Решающее значение в сражениях он придавал тяжелой коннице, что предполагало значительное количество представителей этого вида войска, являвшихся аристократической прослойкой сарматского общества [Хазанов, 2008 , с. 117-182]. Эта точка зрения разделяется не всеми авторами. А.В. Симоненко отмечал, что катафрактарии, как отдельное войсковое подразделение со своими специфическими задачами, не могли появиться в сарматском кочевом обществе. Такого рода конница могла использоваться только в армиях развитых государств, которые могли обеспечить ее формирование. Тяжелое вооружение было доступно только незначительной части сарматов - преимущественно знати, кроме того, нет данных о том, сводились ли они в отдельные воинские подразделения. Основной контингент сарматского войска составляла, по всей вероятности, легкая конница, состоящая из рядового мужского населения [Симоненко, 2008, c. 276; 2010, с. 244-251]. Археологический материал не подтверждает наличие большого количества тяжеловооруженной конницы в рассматриваемое время у сарматов.

Существует мнение о том, что в военных акциях принимали участие сарматские женщины. Оно было основано, с одной стороны, на данных письменных источников (Псевдо-Гиппократ, Помпоний Мела), с другой археологии. Версия античных авторов о воинственности сарматок в значительной мере опиралась на популярную легенду об участии амазонок в происхождении савроматов, которые отождествлялись с сарматами. Археологическим подтверждением этой версии считалось нахождение в сарматских женских погребениях предметов вооружения. А.М. Хазанов полагал, что участие женщин в военных действиях было более характерным для савроматского и раннесарматского времени, а в среднесарматское время они уже практически не принимают в них участия, однако он, 
ссылаясь на археологические данные, не исключал наличие отдельных сарматских воительниц и в это, и в более позднее время [Хазанов, 2008, с. 149, 177]. Видимо, участие сарматских женщин в боевых действиях имело место в крайних случаях, когда происходило нападение на их территорию превосходящего по силам противника или при защите своего стойбища в отсутствии мужчин [Симоненко, 2010$, c. 251,252$]$.

Существовали ли у сарматов зависимые категории населения? В письменных источниках мы не находим каких-либо данных на этот счет. Страбон, называя Танаис торговым центром для азиатских и европейских кочевников, отмечал, что в обмен на «одежду, вино и все прочие принадлежности культурного обихода» они, кроме разных товаров, привозят рабов (Strabo, XI, II, 3). В этом сюжете под азиатскими и европейскими кочевниками во времена Страбона в первую очередь следует подразумевать сарматов, которые соседствовали с городом Танаисом как с востока, так и с запада. У Страбона, видимо, речь идет о продаже кочевниками людей, иноплеменников, захваченных ими в плен, поскольку рабство в кочевых обществах не получило широкого распространения. Специфика экономики кочевников, в отличие от земледельческих обществ, не требовала больших человеческих ресурсов. Об отсутствии значительной категории зависимого населения у сарматов в рассматриваемое время свидетельствует и такой факт, как отсутствие сопровождения погребений высшей знати погребениями зависимых людей, в отличие от скифской практики.

Данные археологических источников. Основным объектом исследования являлись подкурганные погребения среднесарматского времени с территории Нижнего Поволжья. Всего было привлечено 157 погребальных комплексов. Такое количество объясняется условием исследования, наличием в исследуемых комплексах антропологического материала, дающего возможность определить пол и возраст погребенного. В общий список было включено несколько погребений из богатых ограбленных курганов, имеющих важное значение для исследуемой темы. В первую очередь были использованы материалы курганных могильников, в которых погребения среднесарматского времени представлены сериями.

В Заволжье это курганные группы Бережновка I, II, южная группа, курганный могильник Калиновка. В междуречье Волги и Дона: могильники Первомайский VII, Перегрузное I, Аксай I, II, III, Старица. Кроме того, в общий список были включены отдельные среднесарматские погребения из разных районов Нижнего Поволжья.

Все данные о привлеченных среднесарматских погребальных комплексах, включающие детали погребального обряда и все элементы материальной культуры, были внесены в общую таблицу, позволяющую производить их сопоставление.

Знакомство с собранным материалом позволяет утверждать, что погребальная обрядность сарматов рассматриваемого времени отражает различия в их общественном положении. По целому ряду признаков были выделены захоронения сарматской знати. К таковым относятся погребения в курганных могильниках Октябрьский V, кург. 1 [Мыськов, Кияшко, Скрипкин, 1999, с. 149-167]; Жутово, кург. 28 [Скрипкин, Клепиков, 2013, с. 108, 109]; Бердия, кург. 3 [Сергацков, 2000, с. 6771]; Калиновка, кург. 55, погр. 8 [Шилов, 1959 , c. 402-404]; Косика (Бэровский бугор) [Дворниченко, Федоров-Давыдов, 1989, с. 5-13]; Аксай II, кург. 34; Аксай III, кург. 3, погр. 1; Перегрузное, кург. 45; Перегрузное, кург. 51, погр. 1 и 2 [Клепиков, 2013, с. 187-190].

Каков статус погребенных в этих курганах? Установлено, что в Калиновском кургане и в курганах у ст. Бердия и Аксай II были погребены женщины; а в Октябрьском и Перегрузненском курганах и у с. Косика - мужчины. В Жутовском и Аксайском захоронениях пол погребенных не установлен, поскольку отсутствовал антропологический материал в связи с их ограблением.

В распоряжении исследователей имеются материалы, которые позволяют с некоторой долей вероятности получить представления о погребении сарматских предводителей, наделяемых царским статусом. В 1984 г. на Украинеу с. Пороги в Винницкой области в одном из курганов было раскопано погребение знатного сарматского воина с большим количеством золотых вещей: гривны, браслеты, поясные и 
портупейные пряжки, наконечники ремней, бляшки, детали оформления ножен меча. Там же были найдены серебряный кубок с ручкой в виде фигурки лошади, сложный лук с костяными накладками, железные наконечники стрел, наконечник дротика, две амфоры [Симоненко, Лобай, 1991, с. 6-28]. На ряде этих вещей было обнаружено изображение тамги, известной на ольвийских монетах царя Инисмея, сарматская принадлежность которого убедительно была доказана П.О. Карышковским и принята другими исследователями. Наличие серии тамг Инисмея в погребении у с. Пороги позволило А.В. Симоненко предположить возможность захоронения здесь самого царя, к тому же время сооружения данного погребения - последняя четверть I в. н.э. - совпадает с временем правления Инисмея [Симоненко, Лобай, 1991, с. 62-75].

Таким образом, наличие в сарматских погребениях богато оформленных пояса, меча, а также гривны и серебряного кубка, а также сакральная роль этих вещей в среде ираноязычных кочевников свидетельствует о высоком (царском) статусе погребенных лиц.

Еще один престижный элемент царского погребения у с. Пороги - это величина кургана, она составляла около 4 м. Не следует отрицать трудовые затраты в сарматское время на возведение погребальных сооружений как социально значимый признак. Некорректно сравнивать размеры курганов сарматской знати с курганами скифской знати [Яценко, 2002 , с. 92]. В таком случае, почему бы их не сравнивать с египетскими пирамидами. Скифы и сарматы рассматриваемого периода это разные народы, разные культуры, разное время. Отмечая, что размер курганов среднесарматской культуры следует воспринимать как социальный признак, необходимо сравнивать их в рамках погребальной традиции именно этой культуры. В среднесарматское время не сооружаются огромные курганы, наподобие скифских, но многолетняя полевая практика показывает, что в тех могильниках, в которых сосредоточено большое количество курганов, относящихся к среднесарматской культуре, курганы с наиболее престижными погребениями в них отличаются наибольшими размерами по сравнению с остальными. Значительное количество средне- сарматских курганов в настоящее время в Нижнем Поволжье имеет высоту от 0,5 м и ниже, тогда как высота курганов с престижными захоронениями достигает 1-2 м.

Наиболее характерными деталями погребального обряда и материальной культуры выделенных выше десяти престижных подкурганных захоронений являются следующие: в погребальном обряде - наиболее крупные насыпи в курганных могильниках, широкие прямоугольные ямы, наличие тайников, в качестве заупокойной пищи встречаемость костей лошади и крупного рогатого скота; в материальной культуре - наличие вещей, изготовленных из золота (гривна, пектораль, браслеты, серьги, нашивные золотые бляшки), серебряные кубки с зооморфными ручками, чаши из серебра, стекла и алебастра, бронзовые котлы, клинковое оружие, колчаны со стрелами, детали конской упряжи.

Теперь несколько подробнее о каждой из этих характерных черт. Относительно величины курганной насыпи как социального показателя. В среднесарматское время значительно увеличивается количество погребений под индивидуальными насыпями по сравнению с раннесарматским временем, в нашей выборке оно равно $55 \%$. По этой причине мы имеем представление о реальных размерах среднесарматских курганов. Так, из 88 курганов с основными погребениями подавляющая их часть - 79 курганов - не превышала 0,7 м в высоту. Восемь курганов имело высоту более метра, причем значительная их часть находилась на интенсивно распахиваемых в последнее время полях. Так, наиболее высокие среднесарматские курганы у с. Перегрузное на топографических картах середины прошлого века имели высоту 2 м. Стремление погребать престижных персон в больших более ранних курганах было также характерно для среднесарматского времени. Так, калиновское погребение 8 было сооружено в одном из наиболее высоких курганов в могильнике, относящемся к бронзовому веку, его высота $-2,6$ м. Аналогией этому примеру является известное захоронение знатной сарматки I в. н.э. в кургане Соколова Могила на Южном Буге, возведенном в бронзовом веке, высотой 6,4 м. Престижное погребение у с. Косика в Астраханской области было сооруже- 
но на вершине Бэровского бугра. Таким образом, наиболее высокие среднесарматские курганы в одновременных могильниках содержали погребения более знатных персон. Даже в могильнике Аксай II, где курганные насыпи еле просматривались, наиболее крупный курган № 34 среднесарматского времени высотой 0,59 м содержал самое богатое погребение в могильнике.

Для элитных среднесарматских захоронений характерно сооружение широких прямоугольных ям. Из приведенных выше десяти погребений девять были совершены в таких ямах, одно погребение (Аксай II, кург. 34) имело яму удлиненной прямоугольной формы. В некоторых ямах этой группы погребений были зафиксированы на дне деревянные решетчатые настилы (Перегрузное, кург. 45, 51).

Исключительно в этой категории погребений сооружались тайники в полу ямы или в виде ниши в ее стенке. Из десяти ям в семи находились тайники, в которых помещались различные вещи, чаще металлические и глиняные сосуды, конская узда.

Из жертвенной пищи в погребениях среднесарматской культуры обычно встречается передняя нога овцы, часто с лопаткой, и только преимущественно в элитных захоронениях отмечены находки костей лошади и крупного рогатого скота. Если встречаемость костей крупного рогатого скота во всей выборке среднесарматских погребений составляет $4,5 \%$, а лошади $-3,2 \%$, то совокупная встречаемость костей этих животных в погребениях знати равна $30 \%$.

Отличительной чертой погребального обряда среднесарматской знати являлся подбор вещевого реквизита, который включает предметы, являющиеся символами власти или наделенные сакральными функциями. Гривна и пектораль, изготовленные из золота, обнаруженные, соответственно, в калиновском кургане 55, погребение 8, и в погребении у с. Косика, следует интерпретировать как символы власти. У ираноязычных кочевников раннего железного века, к которым относятся и сарматы, находки этих вещей обычны в погребениях высшей знати, ранга царских. Они известны у саков Средней Азии [Акишев, 1978], скифов Северного Причерноморья [Cо- кровища скифских курганов ..., 1966] , кочевников Южного Урала [Яблонский, 2013].

Погребальная одежда сарматской знати украшалась золотыми нашивными бляшками. Эта традиция также типична для захоронений знати скифского времени. Из десяти выделенных среднесарматских престижных погребений такие бляшки были обнаружены в восьми случаях. Есть основания полагать, что и при жизни одежда представителей кочевой знати украшалась золотыми бляшками.

В девяти случаях из десяти в погребениях среднесарматской знати были обнаружены чаши или кубки, в большинстве своем изготовленные из серебра, две чаши из стекла и одна из алебастра. Выделяются серебряные кубки с ручками в виде фигурок животных (Октябрьский V, кург. 1; Перегрузное, кург. 51, погр. 2), они являются частью представительной группы таких кубков, происходящих из самых богатых одновременных погребений сарматской знати Нижнего Дона и Северного Причерноморья [Засецкая, 2011, c. 160-195; Симоненко, Лобай, 1991, с. 58-60]. Исследователи предполагают ритуальное назначение таких сосудов. Зооморфные ручки на сосудах играли роль оберегов. Они были выполнены в виде фигурок лошади, лося, волка, пантеры, зайца. Разнообразие персонажей, изображавших ручки, видимо свидетельствует о том, что эти сосуды принадлежали представителям разных знатных родов, покровителями которых являлись изображаемые животные. Использование их в культовых церемониях подтверждается изображением персон, держащими такие сосуды в руках у пояса. Такие изображения найдены в Кобяковском кургане, Соколовой могиле, хут. Алитуб [Засецкая, 2011, с. 175].

Другой знаковой категорией находок в погребениях среднесарматской знати являются бронзовые котлы. Они обнаружены в семи из десяти наиболее престижных среднесарматских погребений нашей выборки. Причем в двух случаях они обнаружены в двух экземплярах в одном погребении (Октябрьский V, кург. 1; Аксай II, кург. 34). В одном ограбленном погребении в тайнике находились сразу три котла, два литых и один кованый, кроме того, там обнаружен еще бронзовый сосуд с широким горлом (Бердия, кург. 3). В Жутовс- 
ком ограбленном погребении был обнаружен кратер, изготовленный из серебра, который мог выполнять функции котла. Кстати, условия его находки сходны с находкой бронзового котла в погребении у ст. Бердия. В обоих случаях они накрывали другие сосуды, помещенные в погребения.

Как уже неоднократно отмечалось исследователями, котлы помещались преимущественно в престижные кочевнические погребения скифо-сарматского времени. Существует мнение, что котлы служили символом, объединяющим людей, принимающих пищу из одного сосуда. С.А. Плетнева называла котлы кочевников «символами единства» и «символами власти» [Плетнева, 1982, с. 22, 23]. Это мнение находит подтверждение и в археологических материалах Скифии. Котлы у скифов являлись сакральными предметами, их, как правило, находят в погребениях лиц самого высокого ранга, фигурирующих в источниках как «басилевсы» или «номархи». В скифских богатых захоронениях также встречается по нескольку котлов. Есть основание предполагать, что в данном случае имеет место передача сакрального символа как признание власти более сильного правителя, оформляемая в виде скрепления дружбы. Такая ситуация могла объясняться и военным подчинением более мелких кочевых подразделений. В каждом случае это, скорее всего, может объясняться «объединением мелких социумов в более крупные политические образования» [Кузнецова, 2008, с. 184].

Как уже отмечалось, основным видом войска у сарматов в это время являлась легкая конница. Однако конские атрибуты весьма слабо представлены в их погребальной обрядности. Из всей выборки только в восьми погребениях были обнаружены детали конской узды, что составляет около $5 \%$ встречаемости этой категории находок. В выделенных элитных сарматских погребениях процент гораздо выше. Детали узды (удила) встречены в четырех погребениях (40 \%), возможно этот процент был и выше, поскольку ряд погребений этой группы оказался разрушенным.

Обращает внимание находка в одном погребении (Октябрьский V, кург. 1) пяти наборов железных удил с псалиями, причем в каждом случае псалии отличались деталями формы. Это напоминает находки большого количества лошадей и конской узды в известном скифском кургане Аржан в Туве. Исследователь этого кургана М.П. Грязнов считал, что это приношения разных племен своему вождю, он писал: «Вряд ли можно сомневаться, что уздечки и остальные детали конской сбруи... принесены общественными коллективами одной культуры, хотя по различию в отдельных деталях можно предполагать принадлежность их разным этнографическим подразделениям» [Грязнов, 1980, с. 47].

Таким образом, можно предположить, что в октябрьском кургане захоронен предводитель, возглавлявший несколько сарматских подразделений. К тому же в этом погребении обнаружено два котла, что также свидетельствует о возможности объединительной тенденции разных групп кочевников. Кроме того, здесь же были найдены два бронзовых таза; две чаши из серебра с позолотой; два серебряных кубка, один из них с ручкой в виде фигурки зайца; стеклянный канфар; золотые нашивные бляшки в количестве 3155 штук; длинный железный меч; железные наконечники стрел; золотая поясная пряжка; несколько золотых деталей (наконечники, обойма, «пуговицы»), видимо украшавших пояс; золотая обкладка жезла с зооморфным изображением.

Само погребение отличается нестандартностью. Из костей скелета погребенного мужчины 50-60-летнего возраста в анатомическом порядке лежали только кости левой руки и череп, остальные кости были аккуратно сложены в кучку ниже черепа на пространстве 0,75 м. Следов ограбления погребения не было выявлено, что предполагает первоначальное положение погребенного. Возможно, что умерший был погребен по прошествии какого-то времени после смерти. Могильная яма состояла из двух деревянных перекрытий - нижнего, опиравшегося на заплечики, и верхнего, опиравшегося на края ямы.

Судя по набору сопровождающих вещей и их смысловому назначению, погребение в кургане 1 могильника Октябрьский V следует относить к высшей сарматской знати, возможно ранга упоминаемых в письменных источниках сарматских царей. К этому кругу относятся захоронения у с. Косика и погребение 8 из кургана 55 Калиновского могильника. 
В первом из них обнаружена золотая пектораль, во втором - гривна, являвшиеся символами власти, в обоих погребениях обнаружены золотые браслеты, одежда погребенных была украшена золотыми нашивными бляшками. Погребенных сопровождали металлические импортные сосуды. В калиновском погребении найдены бронзовый котел, стеклянная чаша и серебряный кубок.

Следует отметить, что погребение в калиновском кургане 55 являлось женским. Более того, в выборке наиболее престижных среднесарматских погребений Нижнего Поволжья, из которых в восьми случаях был определен пол погребенных, пять из них оказались женщинами. Правда, в разрушенном погребении у ст. Бердия обнаружены только кости от женского костяка, но не исключено, что здесь могло быть парное захоронение.

Богатые женские захоронения среднесарматского времени были открыты и в других местах: курган Хохлач, курган 10 из Кобяковского могильника на Нижнем Дону; Соколова Могила на Украине. Особо следует остановиться на погребении в кургане Хохлач, располагавшемся в Новочеркасске. Несмотря на ограбление этого погребения, сохранившиеся в тайнике и тризне находки позволяют восстановить статус погребенной здесь женщины. К социально знаковым предметам здесь в первую очередь относятся золотая диадема, «увенчанная ритуальной сценой, посвященной культу древа жизни со священными животными, и украшенная бюстом богини плодородия Афродиты... по своему восточному происхождению Афродита близка финикийской Астарте, египетской Исиде, вавилоно-ассирийской Иштар, иранской Анахите». Об особом положении погребенной говорят находки деталей деревянного трона, золотой круглодонный кубок с зооморфной ручкой, золотые гривна и браслеты высокохудожественной работы. Исследования всех категорий находок из кургана Хохлач позволяют утверждать, что здесь была погребена сарматская царица, вероятно наделенная функциями верховной жрицы [3асецкая, 2011, с. 245, 246].

Элитные женские захоронения среднесарматского времени отличаются от аналогичных мужских погребений как в Нижнем Поволжье, так и в других районах отсутствием предме- тов вооружения. В трех мужских погребениях представителей сарматской знати Нижнего Поволжья (Октябрьский V, кург. 1; Аксай III, кург. 3, погр. 1; Перегрузное, кург. 51, погр. 1) оружие занимает видное место. В аксайском и перегрузненском погребениях находились в каждом - меч, кинжал и колчаны со стрелами, в октябрьском - длинный меч и стрелы.

Два женских захоронения из числа десяти элитных погребений могут интерпретироваться как погребения жриц (Перегрузное, кург. 45, погр. 3; кург. 51, погр. 2). Наряду со знаковыми предметами, обилием нашивных золотых бляшек в погребении кургана 45 и бронзового котла и серебряного кубка с зооморфной ручкой в погребении 2 из кургана 51, в обоих погребениях находились жезлы, изготовленные из железа. Археологические и этнографические аналогии позволяют интерпретировать их использование в магических ритуалах, связанных с обеспечением плодородия и изобилия. Следует также напомнить, что курганы с этими погребениями отличались наиболее крупными размерами в могильнике [Клепиков, 2013, с. 187-190].

Проделанный выше анализ богатых погребений среднесарматского времени Нижнего Поволжья позволяет сделать следующие выводы:

1. Элитный статус среднесарматских погребений в погребальном обряде определяется более крупными курганами в могильниках одного времени, широкими прямоугольными ямами с тайниками, с положением погребенных по длинной оси ямы; наличием внутримогильных конструкций: деревянных настилов, гробовищ, двойного перекрытия.

2. В вещевом материале - наличием гривны или пекторали; золотых браслетов; обычно большого количества золотых нашивных бляшек, украшавших одежду или покрывала; кубков и чаш из серебра, стекла, других материалов; бронзовых котлов.

3. Мужские и женские богатые погребения среднесарматского времени по вещевому набору отличаются наличием предметов вооружения в мужских погребениях и его отсутствием в женских. В мужских погребениях также чаще встречаются детали конской упряжи.

4. По письменным источникам известно, что в кочевых обществах раннего желез- 
ного века обычно функции вождя и верховного жреца совмещались. Итоги приведенного выше анализа показывают, что в среднесарматское время эти обязанности могли выполнять как мужчины, так и женщины.

5. Обоснование особого положения женщин у сарматов в рассматриваемое время может быть объяснено следующим образом. В I в. н.э. в степях Юго-Восточной Европы появляются аланы, включившие в свой состав, видимо, часть местного аорского населения. Аланы, по мнению исследователей, своим происхождением связаны с районами Средней Азии. Установлено, что для сако-массагетского населения Арало-Каспийского региона характерно сохранение ярко выраженных матриархальных традиций. Фольклорные мотивы сохранили сведения не только о высоком общественном положении женщин в древности у народов Приаралья, но и об их участии в ратных делах, что перекликается с нартским эпосом народов Кавказа и позволяет говорить об единых истоках этого явления [Толстова, 1984, с. 186-206]. В.И. Абаев, анализируя социальный термин «афшин», которым называли правителей области Усрушана в Средней Азии, установил, что он был заимствован ее жителями из массагетской среды. Этот же термин известен и в осетинском языке в значении «хозяйка». Отмеченный лингвистический факт В.И. Абаев объяснял родством массагетов и аланов, полагая, что афшинами в эпоху военной демократии называли знаменитых массагетских и сарматских правительниц [Абаев, 1959, с. 113-116].

6. Сарматские предводители-мужчины, скорее всего, сами возглавляли свои воинские подразделения. Об этом, в частности, говорят письменные источники: там, где речь идет о походах и сражениях, войско возглавляют обычно сарматские цари (данные Страбона, Корнелия Тацита). Сарматские правительницы, видимо, принимали участие в неординарных случаях, что следует из рассказа Полиена о военной акции царицы Амаги против крымских скифов.

7. По состоянию источников трудно провести разграничение между погребениями царей и скептухов. Предположительно, царскими могут быть захоронения в октябрьском кургане, в курганах у с. Косика и ст. Бердия.
8. К числу статусных в среднесарматской культуре относились и захоронения профессиональных жриц, к которым могут быть отнесены захоронения в перегрузненских курганах 45 и 51.

\section{ПРИМЕЧАНИЯ}

${ }^{1}$ Работа выполнена при поддержке гранта РФФИ № 17-11-34009 а(р) «Элиты сарматского общества Волго-Донского региона (проблемы выделения и социальной интерпретации)».

${ }^{2}$ В данном случае титул «царь», который используют переводчики античных текстов, не следует отождествлять с монархической властью государственных правителей, в социально-политическом отношении сарматское общество стояло на уровне вождеств, в которых верховная власть опиралась на консенсус всего взрослого населения.

\section{СПИСОК ЛИТЕРАТУРЫ}

Абаев В. И., 1959. Среднеазиатский политический термин «афшин» // Вестник древней истории. №2. C. 113-116.

Акишев К. А. 1978. Курган Иссык. Искусство саков Казахстана. М. : Искусство. 130 с.

Барфилд Т. Дж., 2009. Опасная граница: кочевые империи и Китай (221 г. до н.э. - 1757 г. н.э.). СПб. : Факультет филологии и искусства СПбГУ ; Нестор-История. 488 с.

Бондаренко Д. М., Коротаев А. В., Крадин Н. Н., 2002. Введение: Социальная эволюция, альтернативы и номадизм // Кочевая альтернатива социальной эволюции. М. : Ин-т Африки РАН. С. 6-25.

Виноградов Ю. Г., 1994. Очерк военно-политической истории сарматов в I в. н.э. // Вестник древней истории. № 2. С. 151-169.

Грязнов М. П., 1980. Аржан. Царский курган раннескифского времени. Л. : Наука. $161 \mathrm{c.}$

Дворниченко В. В., Федоров-Давыдов Г. А., 1989. Памятники сарматской аристократии в Нижнем Поволжье // Сокровища сарматских вождей и древние города Поволжья. М. : Наука. С. 5-13.

Засецкая И. П., 2011. Сокровища кургана Хохлач. Новочеркасский клад. СПб. : Гос. Эрмитаж. 328 с.

Зубарь В. М., 1998. Северный Понт и Римская империя. Киев : Ин-т археологии НАНУ. 200 с.

Клепиков В. М., 2013. Железные «жезлы» сарматских жриц // Материалы VI Международной Кубанской археологической конференции : сб. тр. Краснодар : Экоинвест. С. 187-190.

Крадин Н. Н., 2007. Кочевники Евразии. Алматы : Дайк-Пресс. 416 c. 
Кузнецова Т. М., 2008. Социальные индикаторы в погребальном обряде скифов (бронзовые котлы) // МИАР. № 10. Проблемы современной археологии. Сборник памяти В.А. Башилова. M. : Tayc. C. 173-187.

Мыськов Е. П., Кияшко А. В., Скрипкин А. С., 1999. Погребение сарматской знати с Есауловского Аксая // Нижневолжский археологический вестник. Вып. 2. С. 149-167.

Перевалов С. М., 2014. Аланы: мираж кочевой империи // Вестник Владикавказского НЦ РАН. Т. 14, вып. 2. С. 2-9.

Плетнева С. А., 1982. Кочевники Средневековья. Поиск исторических закономерностей. М. : Наука. 188 c.

Раев Б. А., 2016. Алания как кочевая империя. Китеж-град донской археологии // Наука юга России (Вестник Южного научного центра). T. 12, № 3. C. 122-126.

Сергацков И. В., 2000. Сарматские курганы на Иловле. Волгоград : Изд-во ВолГУ. 396 с.

Симоненко А. В., Лобай Б. И., 1991. Сарматы Северо-Западного Причерноморья в I в. н.э. Киев : Наукова думка. 112 с.

Симоненко А. В., 2008. Тридцать пять лет спустя. Послесловие-комментарий // Хазанов А. М. Избранные научные труды. Очерки военного дела сарматов. 2-е изд. СПб. : Филол. фак. СПбГУ. С. 238-280.

Симоненко А. В., 2010. Сарматские всадники Северного Причерноморья. СПб. : Факультет филологии и искусств СПбГУ ; Нестор-История. $328 \mathrm{c}$.

Скифы, 1992. М. : Высш. шк. 304 с.

Скрипкин А. С., 1996. К вопросу этнической истории сарматов первых веков нашей эры // Beстник древней истории. № 1. С. 160-169.

Скрипкин А. С., Клепиков В. М., 2013. Ранний железный век // Археологическое наследие Волгоградской области. Волгоград : Издатель. C. 83-136.

Сокровища скифских курганов в собрании Государственного Эрмитажа, 1966. Л. : Артия ; Сов. худож. $120 \mathrm{c}$.

Толстова Л. С., 1984. Исторические предания Южного Приаралья. М. : Наука. 245 с.

Хазанов А. М., 2002. Кочевники и внешний мир. Алматы : Дайк-Пресс. 604 с.

Хазанов А. М., 2008. Избранные научные труды. Очерки военного дела сарматов. 2-е изд. СПб. : Филол. фак. СПбГУ. 294 с.

Шилов В. П., 1959. Калиновский курганный могильник // Материалы и исследования по археологии СССР. № 60. Древности Нижнего Поволжья. Т. 1. М. : Изд-во Акад. наук СССР. С. $323-523$.
Щукин М. Б., 1995. Две реплики о Фарзое и надписи из Мангупа, о царе Артавасде и погребении в Косике // Вестник древней истории. № 4. С. $175-179$.

Яблонский Л. Т., 2013. Золото сарматских вождей. Элитный некрополь Филипповка I (по материалам раскопок 2004-2009 гг.). Каталог коллекций. Кн. 1. М. : ИА РАН. 232 с.

Яценко С. А., 2002. Особенности общественного развития сармато-аланов и их восприятия в других культурах // Кочевая альтернатива социальной эволюции. М. : Ин-т Африки РАН. С. 91-97.

Яценко С. А., 2008. Донская Алания как кочевая империя // Монгольская империя и кочевой мир. Кн. 3. Улан-Удэ : Изд-во БНЦ СО РАН. C. $281-310$.

\section{СПИСОК СОКРАЩЕНИЙ}

БНЦ СО РАН - Бурятский научный центр Сибирского отделения РАН.

ВДИ - Вестник древней истории.

ВолГУ - Волгоградский государственный университет.

ИА РАН - Институт археологии РАН.

МИА - Материалы и исследования по археологии.

\section{REFERENCES}

Abaev V.I., 1959. Central Asian political term Afshin. Journal of Ancient History, no. 2, pp. 113-116. (in Russian).

Akishev K.A., 1978. The Issyk Barrow. The Saka art of Kazakhstan. Moscow, Iskusstvo Publ. 130 p. (in Russian).

Barfield T.J., 2009. The Perilous Frontier: Nomadic Empires and China. 221 BC to AD 1757. Saint Petersburg, Izd-vo Fakultet filologii i iskusstva SPbGU; Nestor-Istoriia Publ. 488 p. (in Russian).

Bondarenko D.M., Korotaev A.V., Kradin N.N., 2002. Introduction: Social Evolution, Alternatives and Nomadism. Nomadic alternative of social evolution. Moscow, Izd-vo Instituta Afriki RAN, pp. 6-25. (in Russian).

Vinogradov Yu.G., 1994. Essay of military and political history of Sarmatians in the $1^{\text {st }}$ century AD. Journal of Ancient History, no. 2, pp. 151-196. (in Russian).

Gryaznov M.P., 1980. Argens. Royal mound of early Scythian time. Leningrad, Nauka Publ. 161 p. (in Russian).

Dvornichenko V.V., Fedorov-Davydov G.A., 1989. Monuments of Sarmatian nobility in the Lower Volga region. Treasures of Sarmatian leaders 
and ancient cities of the Volga region. Moscow, Nauka Publ., pp. 5-13. (in Russian).

Zasetskaya I.P., 2011. Treasures from the Khokhlach barrow. Hoard of Novocherkassk. Saint Petersburg, Izd-vo Gosudarstvennogo Ermitazha. 328 p. (in Russian).

Zubar V.M., 1998. The Northern Pontus and the Roman Empire. Kiev, Izd-vo Institut arkheologii NANU. 200 p. (in Russian).

Klepikov V.M., 2013. Iron "rods" Sarmatian priestesses. Proceedings of the $6^{\text {th }}$ international Kuban archaeological conference: collected works. Krasnodar, Ekoinvest Publ., pp. 187-190. (in Russian).

Kradin N.N., 2007. The Nomads of Eurasia. Almaty, Daik Press Publ. 416 p. (in Russian).

Kuznetsova T.M., 2008. Social indicators in the funeral rite of the Scythians (bronze cauldrons). Proceedings and research on archaeology of Russia. Iss. 10. The problems of modern archaeology. Collected works in memory of V. A. Bashilov. Moscow, Taus Publ., pp. 173-187. (in Russian).

Myskov E.P., Kiyashko A.V., Skripkin A.S., 1999. The burial of Sarmatian nobility at Esaulovskiy Aksay. The Lower Volga Archaeological Bulletin, vol. 2, pp. 149-167. (in Russian).

Perevalov S.M., 2014. Alans: Mirage of nomadic Empire. Journal of Vladikavkaz Scientific Center, vol. 14, no. 2, pp. 2-9. (in Russian).

Pletneva S.A., 1982. Nomads of Middle Ages. The search for historical laws. Moscow, Nauka Publ. 188 p. (in Russian).

Raev B.A., 2016. Alania as a nomadic Empire. Kitezhgrad of the archaeology of the Don. Science in the South Russia (Journal of the Southern Scientific Centre), vol. 12, no. 3, pp. 122-126. (in Russian).

Sergatskov I.V., 2000. Sarmatian Burial Mounds on the Ilovlya river. Volgograd, Izd-vo VolGU. 396 p. (in Russian).

Simonenko A.V., Lobai B.I., 1991. The Sarmatians and the North Pontic area in the 1st century AD. Kiev, Naukova dumka Publ. 112 p.

Simonenko A.V., 2008. Thirty-five years later. Epiloguereview. Khazanov A.M. Selected scientific works. Essays of military affairs. Saint Petersburg, Izd-vo Filol. fak. SPbGU, pp. 238280. (in Russian).
Simonenko A.V., 2010. Sarmatian riders of the Northern Pontic region. Saint Petersburg, Izd-vo Fakulteta filologii i iskusstv SPbGU; Nestor-Istoriya Publ. 328 p. (in Russian).

The Scythians, 1992. Moscow, Vysshaya shkola Publ. 304 p. (in Russian).

Skripkin A.S., 1996. To the Question of Ethnic History of Sarmatians of the First Centuries AD. Journal of Ancient History, no. 1, pp. 160-169. (in Russian).

Skripkin A.S., Klepikov V.M., 2013. Early Iron Age. Archaeological heritage of the Volgograd Region. Volgograd, Izdatel Publ., pp. 83-136. (in Russian).

Treasures of the Scythian burial mounds in the collection of the State Hermitage, 1966. Leningrad, Artiya Publ.; Sovetskiy khudozhnik Publ. 120 p. (in Russian).

Tolstova L.S., 1984. Historical legends of the Southern Aral Sea. Moscow, Nauka Publ. 245 p. (in Russian).

Khazanov A.M., 2002. Nomads and the Outside World. Almaty, Dayk-Press Publ. 604 p. (in Russian).

Khazanov A.M., 2008. Selected Scientific Works. Essays on the Art of Warfare of the Sarmatians. Saint Petersburg, Izd-vo Filol. fak. SPbGU. 294 p. (in Russian).

Shilov V.P., 1959. Kalinovsky burial mound. Proceedings and research on archaeology of the USSR. Vol. 1. Antiquities of the Lower Volga region. Moscow, Izd-vo Akademii nauk SSSR, no. 60 , pp. 323-523. (in Russian).

Shchukin M.B., 1995. Two replicas about Farzoy and inscription from Mangup about the king Artavazd and the burial at Kosika. Journal of Ancient History, no. 4, pp. 175-179. (in Russian).

Yablonskiy L.T., 2013. Gold of the Sarmatian Leaders. Elite necropolis of Filippovka I (on the materials of the excavations of 2004-2009). Catalogue of collections. Book 1. Moscow, IA RAN Publ. 232 p. (in Russian).

Yatsenko S.A., 2002. Features of social development of the Sarmatians-Alans and their reception in other cultures. Nomadic alternative of social evolution. Moscow, Institut Afriki RAN, pp. 91-97.

Yatsenko S.A., 2008. Alania on Don as the Nomadic Empire (the 1st - mid. 2nd cc. AD). Mongolian Empire and nomadic world. Book 3. Ulan-Ude, Izd-vo BNTs SO RAN, pp. 281-310. 
A.S. Skripkin. About the Elite of Middle Sarmatian Society Based on Archaeological Materials

\section{Information about the Author}

Anatoliy S. Skripkin, Doctor of Sciences (History), Professor, Department of Archaeology, Foreign History and Tourism, Volgograd State University, Prosp. Universitetsky, 100, 400062 Volgograd, Russian Federation, anatoly.skripkin@volsu.ru, adsi@volsu.ru.

\section{Информация об авторе}

Анатолий Степанович Скрипкин, доктор исторических наук, профессор кафедры археологии, зарубежной истории и туризма, Волгоградский государственный университет, просп. Университетский, 100, 400062 г. Волгоград, Российская Федерация, anatoly.skripkin@volsu.ru, adsi@volsu.ru. 